\title{
WORK ENGAGEMENT, EMPOWERMENT AND LEADERSHIP STYLES: ANALYSES FROM CULTURAL PERSPECTIVES IN HOTEL MANAGEMENT
}

\author{
E. Sevinç ÇAĞLAR \\ Beykent University, Istanbul, Turkey
}

\begin{abstract}
Tremendous pressure is put both on people and organizations, to improve their performance in a rocket fast changing, extremely competitive business world (Stander \& Rothman, 2010). High performance is considered as indispensible but extraordinary performance is what people are pursuing today. Insomuch that mere motivation, satisfaction or devotion of employees will remain insufficient but bursts of energy to work is what needed. Work engagement fits best to this context. Till today; piled up research on work engagement indicate its positive relations with job satisfaction, organizational commitment, and citizenship behavior. It is known that engaged employees are more productive and report higher levels of health and well-being (Laschinger et al., 2008; Bakker \& Demerouti, 2007; Schaufeli \& Bakker, 2004). The link between financial returns and positive outcomes as employee satisfaction, motivation or work engagement has also been set forth (Xanthopoulou et al.,2009; Harter et al., 2002). Both practice and research put forward that employees need to feel and be empowered to be truly engaged. Major aim of this study is to figure out the impact of empowerment on engagement and the most effective leadership style for employees to perceive empowerment that will lead them to be engaged. Some of the existing studies in literature signal the culture-bound effect of leadership style for employees to respond positively on empowering practices (Avolio et al., 2004; Pellegrini \& Scandura, 2006). The sample of the present research consists of 621 managers and employees attending from 18 hotels (4 and over star) located in Istanbul and Antalya cities. Correlation and multiple regression analyses are conducted to test the hypotheses besides factor and reliability analyses of the research instruments. Demographics are also examined by using ANOVA and t-tests to find out group differences. Findings indicate factors of empowerment external to the employees such as organizations' culture, climate, or management practices all contribute to the levels of work engagement through partial mediation of employees' empowerment perception. Leadership styles moderate the relation between external factors and perception of empowerment in which nourishing style has the most contribution. World chain hotels score highest for both domains of empowerment and work engagement that tend to increase with age, tenure, and position of the employees.
\end{abstract}

Keywords: work engagement, empowerment, leadership styles, nourishing leadership

\section{INTRODUCTION}

Tremendous pressure is put both on people and organizations, to improve their performance in a rocket fast changing, extremely competitive business world (Stander \& Rothman, 2010). Adapting successfully to such an astonishingly unstable environment requires extreme flexibility, risk-taking, continuous learning, networking, ethical visioning and measurable outcomes. High performance is considered as indispensible but extraordinary performance is what people are pursuing today. It is so clear for companies that reaching these highly challenging outcomes is impossible without motivated, satisfied, and devoted employees. Furthermore, bursts of energy and activation to work is what needed. As much as practitioners in management, academicians also get involved to find out the ways of attaining these very desirable ends. Work engagement and employee empowerment are considered to be fully relevant issues in this context. In academic community, research on them has started to pile up in recent years.

Academic research on work engagement indicate that it is positively related to desired outcomes such as job satisfaction, organizational commitment, and citizenship behavior. It is known that engaged employees are more productive and report higher levels of health and well-being (Laschinger et al., 
2008; Bakker \& Demerouti, 2008; Schaufeli \& Bakker, 2004). The link between financial returns and positive outcomes as employee satisfaction, motivation or work engagement has also been set forth Xanthopoulou et al., 2009; Harter et al., 2002).

Piersol (2007) after working many years as a chief consultant in North America Defense Company assigned to NATO puts forward that employees need to feel and be empowered to be truly engaged. Similar to engagement; research on empowerment indicates that it is a powerful mechanism for increasing employee involvement in organizational activities that result in greater job satisfaction and increased organizational productivity (Laschinger et al., 2009a; Laschinger et al., 2009b).

Empowerment is a highly complicated construct, reviewed from different angles by various theorists. An in-depth study of literature points out the two main streams of the perspectives dealing with factors that give birth to empowerment. One path relates it with factors subject to the person himself whereas the other points out the outside factors that are external to the person. In this study it is assumed that external factors will impact the level of engagement as much as they are perceived by the employees. The relation between external and perceived empowerment will be moderated by leadership styles.

Some of the existing studies in literature signal the culture-bound effect of leadership style for employees to respond positively on empowering practices (Avolio et al., 2004; Pellegrini \& Scandura, 2006). Research conducted in Western countries such as in United States or Europe mostly emphasize the positive contribution of transformational leadership style on empowerment. However, this is considered to be prevailing in Western cultures that are characterized as individualistic, exhibiting low power distance and uncertainty avoidance based on cultural dimensions identified by Hofstede (2001). Avolio and friends' (2004) research in Singapore or Pellegrini and Scandura's (2006) analysis in Turkish banking sector are indicative studies supporting this perspective. The present research gives another opportunity to see the impact of culture and culturally formed leader behavior on empowerment effectiveness, an issue that continues to be debatable.

Avolio and his friends' (2004) findings exhibit that transformational leadership style to be more effective on organizational commitment when structural distance is low between the leader and the follower. High structural distance indicates a hierarchical relationship which is the characteristic of high-power distance cultures typical in Eastern counteries, whereas low structural distance implies a more decentralized, closer leader-follower interaction.

Pellegrini and Scandura (2006) based on their research findings note that the delegation of decisionmaking is not an effective management technique in every culture. Its effectiveness may be contingent on national culture. Employees in high-power distance cultures may expect the leader to take charge and give orders, rather than delegate decision-making authority to the subordinate. Turkey is high on uncertainty avoidance, which suggests that employees may prefer to be told exactly what to do instead of the ambiguity of being delegated a challenging task. Their results also suggest that, with respect to job satisfaction, followers in the Turkish business context may be disinterested in delegation. In the traditional Turkish business environment paternalism is found to be a salient dimension influencing both high-quality LMX relations and employee job satisfaction.

The present research is aimed to be conducted in service sector. It is because as Bowen and Lawler (1992) point out, the concepts of empowerment and work engagement contain more importance in service sector, where social relationships and emotional labor are more intensely experienced. In this regard, hotels are thought to represent conveniently the research audience. Tourism, as it is taking a considerable part in Turkey's economical development, is a positive factor for utility of the research. The present study provides clues for hotel managers in the way of increasing employee engagement which will apparently generate more customer satisfaction.

\section{Theoretical Framework and Hypotheses}

\section{Work Engagement}

Literature on work engagement points out the two main theoretical approaches. One of them is Maslach and friends' (2001) view which deals with engagement as the opposite end of burnout. Second one is Schaufeli's thesis that frames it as a separate construct other than burnout. Schaufeli and colleagues define engagement "as a positive, fulfilling, work-related state of mind that is characterized by vigor, dedication, and absorption." They further state that it is not a momentary and specific state, but rather "a more persistent and pervasive affective-cognitive state that is not focused on any particular object, event, individual, or behavior" (Saks, 2006). 
This paper takes Schaufeli's perspective in analyzing work engagement. The dimensions are explained as follows: Vigor is characterized by high levels of energy and mental resilience while working, the willingness to invest effort in one's work, and persistence even in the face of difficulties. Dedication is characterized by a sense of significance, enthusiasm, inspiration, pride, and challenge. Dedication is a stronger 'involvement' with one's work and a step further than the usual level of 'identification'. Finally, absorption is characterized by being fully concentrated and deeply engrossed in one's work, whereby time passes quickly and one has difficulties with detaching oneself from work. It is a similar concept to 'flow', but the distinction among them lies in the duration of experience. Flow is a more complex concept and refers to a peak experience covering a shorter period of time whereas absorption is more pervasive and persistent state of mind (Schaufeli et al., 2002).

\section{Employee Empowerment}

Empowerment is a multi-dimensional concept exhibiting a complex structure. These dimensions are analyzed through different lenses by various researchers. Even, some writers use different words to imply the same approaches (Honold, 1997). These are complicating factors in clearly operationalizing the concept. Erstad (1997) describes it as a management's change strategy with the objective of improving both the individual's and the organization's ability to act. Bowen and Lawler (1992) define it as a means to enable employees to make decisions. According to Conger and Kanungo (1988) it is the motivational concept of self-efficacy. Thomas and Velthouse (1990) defined it more broadly as increased intrinsic task motivation manifested in a set of four cognitions reflecting an individual's orientation to his or her work role: meaning, competence (which is synonymous with Conger and Kanungo's self-efficacy), self-determination, and impact.

Until the end of 1980s, researchers were focused their work only to external phenomena to empower the employees. Conger and Kanungo's (1988) work is the first that focuses on the psychological experience of empowerment (Spreitzer, 1995).

As a pioneer of the structural perspective, Kanter argued that in order to accomplish the empowerment within an organization; work environments that provide access to information, resources, support, opportunity to learn and develop, are needed. Moreover, the access to these empowering structures is relational with formal and informal power systems within in the organization. Formal power refers to job characteristics that contribute to job recognition within the organization through discretionary actions that are important to the organization's goals. Informal power refers to the development of effective relationships with peers, superior and subordinates within the organization (Patrick. \& Laschinger, 2006). When employees have access to formal and informal power, they have greater access to information, support and resources, and opportunities to learn and grow (Patrick \& Laschinger, 2006b).

Spreitzer (1996); based on Lawler's model of high involvement systems in organizations, describes social structural characteristics of empowerment at the level of work unit. These are namely; role ambiguity, span of control, sociopolitical support, access to information and resources, and work-unit climate. Each characteristic is explained as follows: Role ambiguity is related with uncertainty about employees' responsibilities due on their work roles. Span of control denotes the number of people supervised by one manager. Narrow spans allow for close control and associated with centralized decision making. Large spans mean more decentralized structures that promote the contribution of employees to the operations of their organization. Socio-political support is defined as relevant support networks including an individual's boss, peers, subordinates and the members of his/her work group. Supporting social exchanges among these networks will enhance a sense of personal power and facilitate the cognitions of empowerment. Access to information, allows employees to understand their roles' in the organizations' operations. The mentioned information includes data about work flow, productivity, the external environmental, competition, and firm strategy. Access to resources is reported by many theorists as enhancing an individual's sense of self-efficacy and control over environmental contingencies. These resources are noted as funds, material, space, and time. Participative climate is characterized as supportive atmosphere in organization for acknowledgment, creation, and liberation of employees.

Conger and Kanungo (1988) explain empowerment as a process whereby an individual's belief in his/her self-efficacy is enhanced. Thomas and Velthouse (1990) developed this approach by specifying four cognitive assessments namely; impact, competence, meaningfulness, and choice, people make when they are interpreting the relevant data. However, the validation and measurement 
of the construct in terms of this psychological perspective was not realized until Spreitzer's studies (Spreitzer, 1996).

As noted by Thomas \& Velthouse: Meaning is the value of a work goal or purpose, judged in relation to an individual's own ideals or standards. Meaning involves a fit between the requirements of a work role and beliefs, values, and behaviors (Spreitzer, 1995). Competence, is an individual's belief in his or her capability to perform activities with skill. Self-determination is an individual's sense of having choice in initiating and regulating actions. It reflects autonomy in the initiation and continuation of work behaviors and processes; examples are making decisions about work methods, pace, and effort. Impact is the degree to which an individual can influence strategic, administrative, or operating outcomes at work.

Lin $(1998,2002)$ proposes an integrated model of empowerment. Her model suggests an empowerment process that is created by reciprocal relationships among empowering organizational culture, empowering leadership, empowering managerial practices, and empowered employee. She developed and tested her model in Taiwan which is considered to be critical for this study due to cultural similarities among Turkish and Taiwanese populations. The two countries are ranked close to each other with respect to Hofstede's (2001) cultural dimensions. Turkish culture is evaluated to be collective in nature, high on power distance, and has low tolerance for uncertainty.

In present study; external factors of empowerment process are considered as one variable and the psychological perspective of employees for perceiving themselves to be empowered taken as another variable. Perceived empowerment will be the mediator among externals and work engagement.

Hypothesis 1: Empowering employees will effect work engagement through the mediation of psychological (perceived) empowerment.

\section{Leadership Styles}

Transactional, transformational, laissez-faire, ethical, paternalist and servant leadership styles are in focus of research as they are up-to-date and most relevant to empowerment. Below; brief description and related theorizing of each style is presented.

Transactional Leadership Current literature puts forth three dimensions of transactional leadership: Contingent reward, active and passive management by exception (Judge \& Piccolo, 2004). Among them; contingent reward is specified as the strongest characteristic in determining transactional leadership (Judge \& Piccolo, 2004; Lowe et al.,1996; Podsakoff et al., 1990; Bass,1985). Contingent reward refers to rewarding employees in exchange of their successful, goal-oriented performance. Leader can also appeal to punishment. According to management by exception, a leader does not intervene unless everything is going well and goals are attained. If deviations from standards occur, the leader takes corrective actions. The fact that distinguishes active from passive management by exception is that in active management, the leader monitors followers and do not let them to make mistakes. In such way, incorrect behaviors are prevented before a serious problem occurs. Whereas in passive management, the leader intervenes to problems after they are brought to his/her attention (Howell \& Avolio, 1993; Demir \& Okan, 2008).

Transformational Leadership

In Podsakoff's model of transformational leadership; six categories of defining behaviors are specified: Identifying and articulating a vision, providing an appropriate model, fostering the acceptance of group goals, high performance expectation and intellectual stimulation (Podsakoff et al., 1990). Accordingly; employees are motivated in the way of an attractive, future-oriented vision stated by the leader. This vision is proactive and contains high standards. The leader motivates followers by adding meaning and sense of purpose to the activities that leads to reach the vision (Bass, 1990; Demir \& Okan, 2008; Anderson et al., 2002; Conger, 1999; Luthans, 2008). Employee's innovative behaviors, suggestions and thoughts are supported. An environment in which mistakes are tolerated and calculated risk taking is provided. Employees' mental development, logic and problem solving abilities are encouraged. Individualized support and personal growth of employees are in leader's consideration for his/her each subordinate. The leader acts as the coach and consultant to his/her employees, takes care of their personal problems, self development, desires and needs (Bass, 1985; Conger. \& Kanungo,1987; Bennis \& Nanus, 1986; Anderson, et al., 2002; Podsakoff, et al., 1990).

Laissez-Faire Leadership In general, laissez faire leaders give employees ultimate freedom in performing their job after providing them with needed resources. They do not intervene circumstances 
unless they are asked and do not comment on the outcomes. In management, this style is rare though sometimes defined as the opposite of autocratic leadership (Bass, 1990). For the leaders acting in this style, it is usually thought that they do not have the required knowledge and skills to manage subordinates.

Ethical Leadership Certain similarities exist between ethical and transformational leadership styles. Transformational leaders are also moral, trustful, fair and honest. In both styles, leaders are perceived as role models for followers. But research suggests that these styles are distinguished in terms of intellectual stimulation and implementation of vision facets (Brown et al., 2005; Trevino et al., 2003). Ethical leadership is more contiguous to transactional leadership in terms of practices. Adaptation of moral behaviors on followers by rewarding and punishment reflects contingent reward dimension of transactional leadership style.

Servant Leadership Literature sets forth that servant leadership has much in common with transformational leadership (Barbuto \& Wheeler, 2006). However, it is also established as a separate construct and the most significant fact that distinguishes servant leader from transformational is servant leader's focus on serving his/her followers and the society. Transformational leaders motivate followers in the way of internalizing organizational goals. The goal of servant leaders, on the other hand, is to dedicate themselves entirely to followers by ignoring their own egos and lead them to grow in favor of humanity. In the case of servant leadership, the ultimate goal is not the benefits of organization (Stone et al., 2004). Research findings establish that servant leadership is more effective than transformational leadership on employees' trust in leader, extra role behaviors, organizational citizenship, engagement, expected performance and dedication to society (Liden et al., 2008; Joseph \& Winston, (2005).

Paternalistic Leadership-For paternalist leadership Aycan and her colleagues, are defined five sub dimensions (Aksoy, 2008). These consists of: family atmosphere at work, individualized relationships, involvement in employees non work lives, status-hierarchy-authority and loyalty expectation. By creating a family atmosphere in the workplace he/she behaves like a father to subordinates, giving fatherly advice to subordinates in their professional as well as personal lives. He/she knows every subordinate in person (personal problems, family life, etc.), is genuinely concerned with their welfare, takes close interest in subordinates' professional as well as personal life. Attends important events (e.g., wedding and funeral ceremonies, graduations, etc.) of his subordinates as well as their immediate family members, providing help and assistance (e.g., financial) to subordinates when they need it. He/she expects loyalty. So, employees should immediately attend to an emergency in the company regardless of family lives at the moment. Status differences (position ranks) are important for him/her and expects employees to behave accordingly. He/she believes that he/she knows what is best for subordinates and their career, and even asks subordinates' opinions he/she makes the final decision. Employees' expectations are in this way also (Ergin, 2000; Fikret-Paşa, 2000).

Hypothesis2: Leadership styles will moderate the relation between external empowerment factors and employees' empowerment perceptions. 


\section{Method}

\section{Research Model}

The model is presented in Figure 1 below.

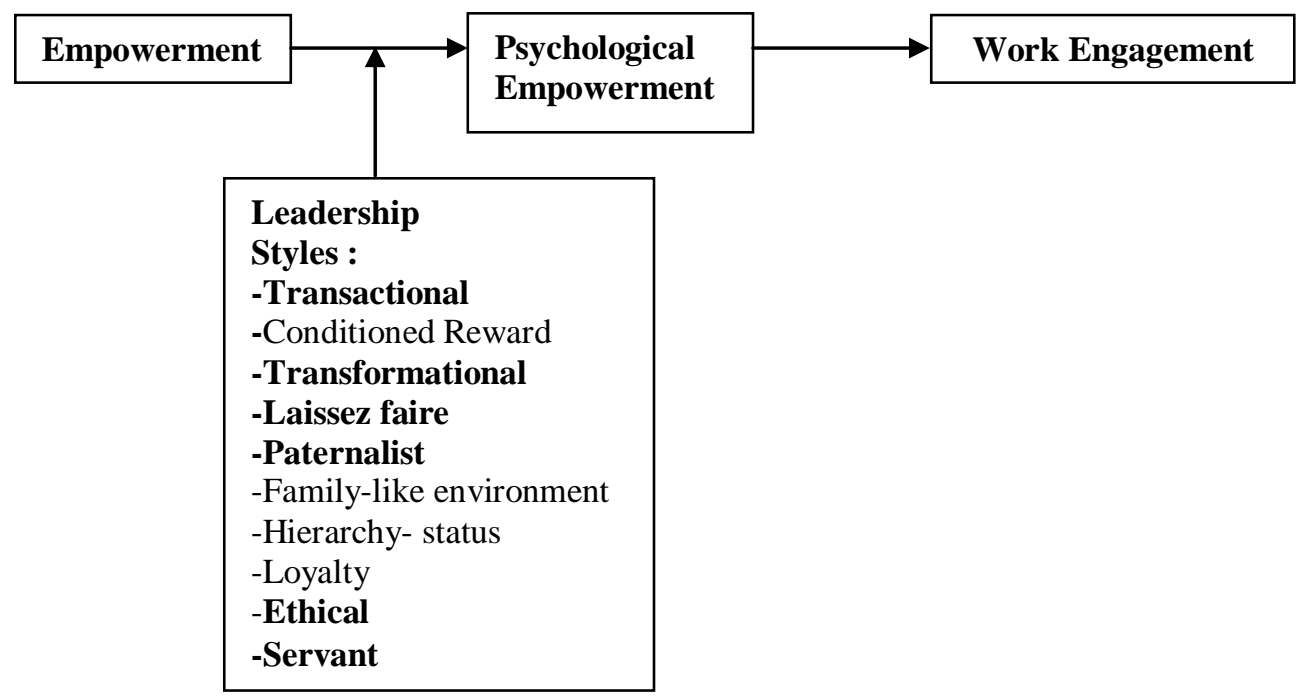

Figure 1. Research Model

\section{Sample}

The sample consists of employees in 4 or more-star hotels. Hotels located in Antalya and Istanbul are involved in the study. A total of 42 hotels were interviewed and 19 of them (8 in Istanbul) replied back positively. As one of these hotels (from Istanbul) did not respond later even it replied positively for the research, a total of 18 hotels participated in the research. The researcher personally distributed the surveys to the hotel employees. The total number of surveys that are distributed is 2180.702 of them were returned. The ones which were not completely answered and or replies of interns, and the ones that were thought to decrease the reliability of the data (such as repeated answers in a questionnaire) were left out of the analysis. After all the eliminations, a total of 621 surveys were involved in the analysis.

\section{Research Instruments}

Empowerment Scales In forming external empowerment questionnaire The CWEQ-II scale developed by Chandler consisting 19 items, Spreitzer's scale of social structure that has 18 items, and Lin's 33-item scale were used. Items that carry out the same meanings in all scales are eliminated by the researcher. Cronbach alphas for CWEQ-II are founded between .73 ve .91( Miller et al., 2001; Patrick. \& Laschinger, 2006; Laschinger et al., 2001; Laschinger, 1996; Laschinger et al., 2008; Laschinger et al., 2009a; Laschinger et al., 2009b). In Spreitzer's scale the values of Cronbach alpha for role ambiguity is found as .61, for the rest of the factors it is above .70 (Spreitzer, 1996). For Lin's scale $(1998,2002)$ the Cronbach alpha values are noted as .94 and .95 respectively.

16 items are taken from Spreitzer's scale. 9 items referring to subjects which are not present in Spreitzer's scale are added from CWEQ-II. 5 items from Lin's scale were added. These items interrogate empowerment culture and practices and they refer to some important points that are not present in the other scales. Consequently, 30 items in total were involved in external empowerment questionnaire.

To measure psychological or perceived empowerment domain, psychological empowerment (PE) scale developed by Spreitzer [22] is used. This one is a frequently used scale in Turkish literature. 12item in total consists of 4 factors: Meaning, competence, self-determination and impact. Each factor contains 3 items. In several studies conducted in Turkey and abroad; the Cronbach alpha values revealed between .83 and .93 (Spreitzer, 1995; Arslantaş, 2007; Aksoy, 2008). 
Answer points range between $(1)=$ Highly disagree, to $(6)=$ Highly agree. High points refer to empowerment existence and employee perceives himself as highly empowered. Low score indicates the opposite.

Leadership Styles Scale Transactional, transformational, laissez-faire, ethical, paternalist and servant leadership styles were the interest of this study. Each style of leadership has commonalities with each other as well as distinctive characteristics. So, items representing only the major defining behavior for each style are included in the questionnaire for practical reasons. Otherwise, too many items would be deterrent for the respondents.

For transactional and transformational leadership items, Podsakoff's (1990) scale is used. Six items that measure transformational leadership, and five items representing contingent reward factor of transactional leadership were included. For paternalist leadership items, scale developed by Aycan and her colleagues are referred (Aksoy, 2008). It consists of five sub dimensions: family atmosphere at work, individualized relationships, involvement in employees non work lives, status-hierarchyauthority and loyalty expectation. Ten items out of 21 are employed. They represent the most significant characteristics that distinguish paternalistic leadership; creating a family environment at work, behaving like a head of family, involving in employees' non-work lives, hierarchical/authoritarian behaviors and consideration of employee loyalty rather than job performance.

Items of ethical leadership scale developed by Brown and his coworkers (2005) are utilized. Six out of ten items are used. For servant leadership, the items of Barbuto and Wheeler's scale (2006) are referred. Servant leaders may differently sacrifice organizational goals to contribute to the development of their employees and society if it is necessary Barbuto \& Wheeler, 2006; Stone et al., 2004).

Total of 38 items reside in leadership style questionnaire. Response scale is based on frequency of exhibiting specified behaviors by managers. Answers range from (1) =Almost never to $(6)=$ Almost always.

Work Engagement (WE) Scale Work engagement is measured by Schaufeli and his colleagues's (2002) 17-item Utrecht Work Engagement Scale (UWES). It consists of three sub dimensions: Vigor (6 items), dedication (5 items) and absorption (6 items). The scale is widely used. Cronbach alpha value for vigor is founded as .81-.90; for dedication, .88-.95 and for absorption, .70-.88 (Schaufeli \& Bakker, 2003). The responses range from (1) $=$ Almost never, to (6) $=$ Almost always.

\section{Results}

\section{Descriptive Statistics}

Findings of analyses demonstrating profile and distribution of the sample are displayed on Table 1. 
Table 1. Descriptive Statistics Results

\begin{tabular}{|c|c|c|c|c|c|}
\hline & Frequency & $\%$ & Standard Deviation & Skewness & Kurtosis \\
\hline City & & &, 478 &,- 618 & $-1,623$ \\
\hline Istanbul & 219 & 35,3 & & & \\
\hline Antalya & 402 & 64,7 & & & \\
\hline Hotel & & & ,909 &,- 073 & $-1,788$ \\
\hline World chain & 245 & 39,5 & & & \\
\hline Turkish chain & 108 & 17,4 & & & \\
\hline Seaside hotels & 268 & 43,2 & & & \\
\hline Gender & & &, 450 &,- 973 & $-1,057$ \\
\hline Female & 151 & 24,3 & & & \\
\hline Male & 385 & 62,0 & & & \\
\hline $\begin{array}{l}\text { Marital Status } \\
\text { Single }\end{array}$ & & & 500 &, 045 & $-2,005$ \\
\hline Married & 273 & 44,0 & & & \\
\hline & 261 & 42,0 & & & \\
\hline Education & & & 674 &,- 087 &,- 794 \\
\hline Elementary/Secondary & 101 & 16,3 & & & \\
\hline High school/Vocational & 284 & 45,7 & & & \\
\hline Under/Post graduate & 139 & 22,4 & & & \\
\hline Age & & & 1,222 & 021 &,- 984 \\
\hline $16-20$ & 39 & 6,3 & & & \\
\hline $21-25$ & 120 & 19,3 & & & \\
\hline $26-30$ & 169 & 27,2 & & & \\
\hline $31-35$ & 92 & 14,8 & & & \\
\hline 36 and over & 114 & 18,4 & & & \\
\hline Vocation & & & 2,230 &,- 328 & $-1,061$ \\
\hline Front desk & 54 & 8,7 & & & \\
\hline Bellboy & 35 & 5,6 & & & \\
\hline Back office & 61 & 9,8 & & & \\
\hline Manager & 42 & 6,8 & & & \\
\hline Service & 99 & 15,9 & & & \\
\hline Housekeeping & 46 & 7,4 & & & \\
\hline Kitchen & 107 & 17,2 & & & \\
\hline Technical/Security/etc. & 66 & 10,6 & & & \\
\hline Work Tenure & & &, 819 &,- 157 & $-1,493$ \\
\hline 1 year and less & 154 & 24,8 & & & \\
\hline $2-4$ & 168 & 27,1 & & & \\
\hline 5 years and more & 198 & 31,9 & & & \\
\hline \multicolumn{6}{|c|}{ Customer Communication } \\
\hline Frequency & & & ,792 &,- 722 & $-1,036$ \\
\hline \multicolumn{6}{|l|}{ Rare } \\
\hline \multicolumn{6}{|l|}{ Average } \\
\hline \multirow[t]{3}{*}{ Frequent } & 104 & 16,7 & & & \\
\hline & 130 & 20,9 & & & \\
\hline & 290 & 46,7 & & & \\
\hline Income & & &, 548 & 072 &,- 187 \\
\hline High & 33 & 5,3 & & & \\
\hline Average & 325 & 52,3 & & & \\
\hline Low & 138 & 22,2 & & & \\
\hline
\end{tabular}

\section{Factor and Reliability Analyses for the Scales}

Factor analysis of work engagement came out in two factors named as "absorption" and "vigor/dedication". 10 items revealing the two factors explain $64.5 \%$ of the total variance. Cronbach alpha value is found to be 0,859 for both factors.

For external empowerment; 25 -items left after iterations and the scale is found to be divided into 5 factors namely; participative climate, support/opportunity, empowering culture and practices, role ambiguity and resource. Cronbach alpha is .910. PE scale loaded into two factors impact/self determination (SD) and meaning/competence. Only 1 item was removed and ended up in 11 items. Cronbach alpha is .905 . 
Leadership scale resulted in 30 items and 3 factors named; nourishing leadership, laissez faire, and authoritarian. The first of the three factors is consisted of transformational, transactional, servant and the sub dimension (family environment creation) of paternalistic leadership items. $37.4 \%$ of the variance is explained by this factor. The second factor contains all items of laissez-faire leadership and a negative item of transactional leadership style. The third factor is formed by hierarchy/status subdimension of paternalistic leadership. Cronbach alpha value for the total scale is .925 .

\section{Correlation analyses}

Engagement is found to be significantly correlated with all of the independent variables. It has the strongest correlation with $\mathrm{PE}(\mathrm{r}=, 366 ; \mathrm{P}<0,01)$. Leadership styles and external empowerment factors showed the highest correlation of all $(r=, 759 ; \mathrm{p}<0,01)$; When the relationship among leadership styles and empowerment is examined in detail; it is found that nourishing leadership style is highly correlated with all factors of empowerment except role ambiguity. On the other hand, role ambiguity is found to be correlated with laissez faire at the 0,609 level. Leadership and empowerment correlations in detail are presented in the table below (see Table 2)

Table 2. Correlation Matrix of Leadership Styles and Empowerment

\begin{tabular}{|c|c|c|c|c|c|c|c|c|}
\hline & 1 & 2 & 3 & 4 & 5 & 6 & 7 & 8 \\
\hline 1. Participative climate & 1 & & & & & & & \\
\hline 2. Support/opportunity &, $577 * *$ & 1 & & & & & & \\
\hline 3. Emp. cult.\& practcs &, $682 * *$ &, $549 * *$ & 1 & & & & & \\
\hline 4. Role ambiguity &, $105^{*}$ & ,078 &, $240 * *$ & 1 & & & & \\
\hline 5. Resource &, $518 * *$ &, $560 * *$ &, $513 * *$ &, $091 *$ & 1 & & & \\
\hline 6. Nourishing &, $681 * *$ &, $621 * *$ &, $591 * *$ &,- 003 &, $510 * *$ & 1 & & \\
\hline 7. Laissez faire &, $137 * *$ &, 004 &, $191 * *$ &, $609 * *$ &, 024 &,$- 103 *$ & 1 & \\
\hline 8.Authoritarian &, $438 * *$ & ,399** &, $431 * *$ &, 063 &, $434 * *$ &, $589 * *$ &, 067 & 1 \\
\hline
\end{tabular}

$* * \mathrm{p}<0,01 ; * \mathrm{p}<0,05$

\section{Regression Analyses}

\section{Hierarchical Regression Analysis of Work Engagement}

All of the variables including the demographics are regressed in order to test their predictability on the dependent variable (work engagement). First model tested the demographic variables which are thought to have the weakest relation with the dependent variable. Next; leadership styles, PE and empowerment are included respectively in regression. For none of the variables, the VIF value exceeded 10, meaning that multi-collinearity does not pose a problem. Detailed regressions for all factors of variables are also conducted. Nourishing and authoritarian styles are found to have significant impact on both factors and the whole of engagement.

The results of the analyses are presented below (see Table 3). Of all the independent variables, only the ones which have significant effects are listed on the table. 
Table 3 Results of Hierarchical Regression Analysis of Work Engagement

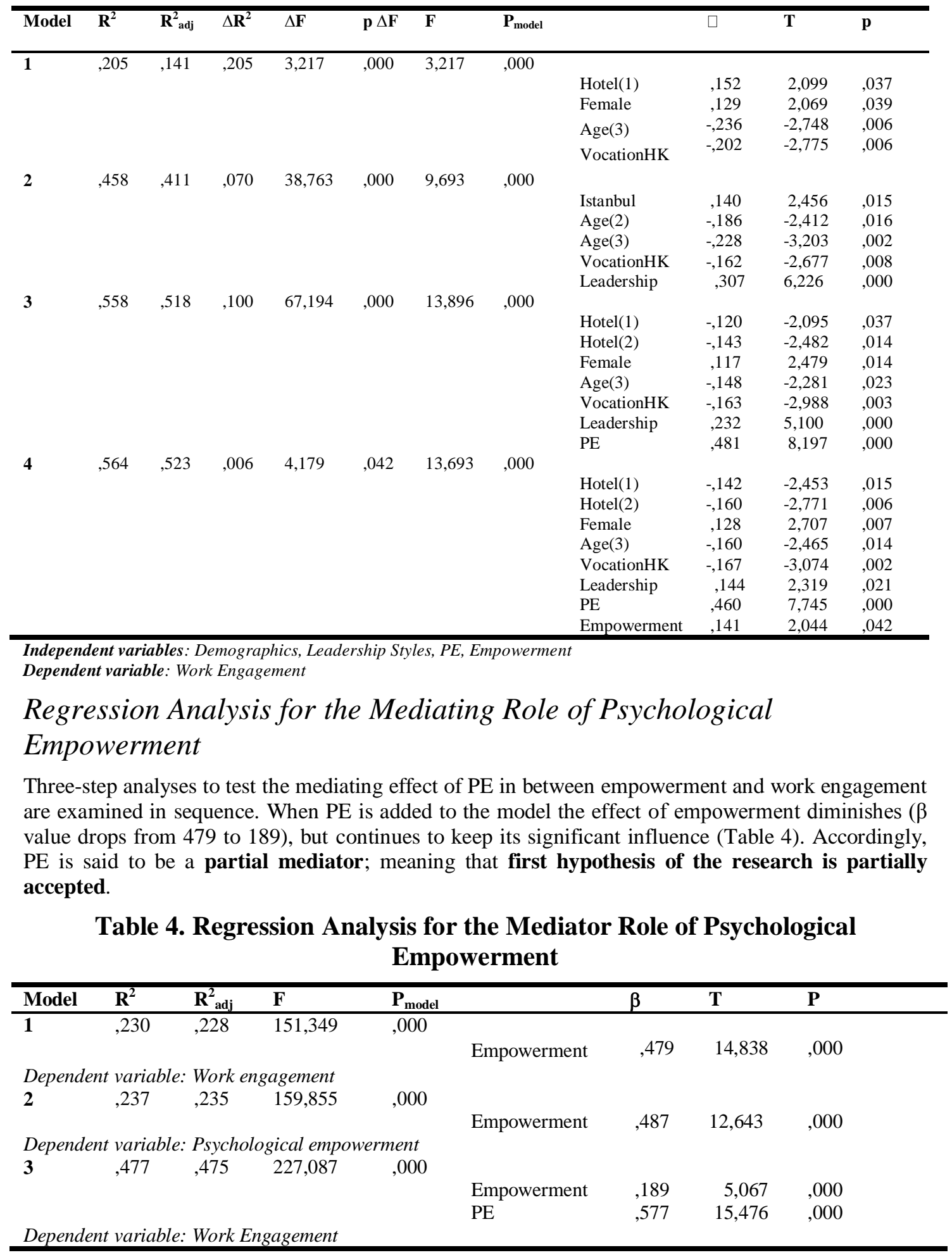




\section{Regression Analysis for the Moderator Role of Leadership Styles between Empowerment and Psychological Empowerment}

In the first analysis carried out by total scores, the interaction of leadership behaviors with empowerment is found to have significant influence on PE. However, leadership behavior alone is not influential on PE (Table 5). The second hypothesis, which suggests the moderator effect of leadership on the relationship between empowerment and psychological empowerment, is said to be supported.

Table 5. Regression Analysis for the Moderator Role of Leadership Styles

\begin{tabular}{|c|c|c|c|c|c|c|c|c|c|c|c|}
\hline Model & $\mathbf{R}^{2}$ & $\mathbf{R}_{\text {adj }}^{2}$ & $\Delta \mathbf{R}^{2}$ & $\Delta \mathbf{F}$ & $\mathbf{p} \Delta \mathbf{F}$ & $\mathbf{F}$ & $\mathbf{P}_{\text {model }}$ & & $\beta$ & $T$ & $\mathbf{P}$ \\
\hline 1 & ,241 & ,239 & 241 & 148,015 &, 000 & 148,015 & ,000 & & & & \\
\hline \multirow{3}{*}{2} & & & & & & & & Empowerment & 491 & 12,166 & ,000 \\
\hline & , 242 & , 2008 & , 001 & (34) & , 401 & 14,208 & , & Empowermen & .525 & 5,157 & .000 \\
\hline & 287 & 283 & 046 & 29972 & 000 & 62539 & 000 & Leaderships &,- 046 &,- 738 & ,461 \\
\hline \multirow{3}{*}{3} & & & & & & & & Empowermen & 494 & 8,161 & ,000 \\
\hline & & & & & & & & Leaderships & ,057 & ,896 &, 370 \\
\hline & & & & & & & & EmpXLeader & ,229 & 5,475 & ,000 \\
\hline
\end{tabular}

Dependent variable: PE

\section{Demographic analyses}

Demographics are tested for each research variable to find out the differentiating groups. World chain hotels demonstrated the highest scores for both domains of empowerment and work engagement, whereas seaside hotels had the lowest. Nourishing leadership style that signifies cultural characteristics is found at most in Turkish chain hotels as expected. Engagement, external factors of empowerment and employees perceptions were all higher in Istanbul than Antalya. Group differences does not exist for education. However, males tend to score higher than females in terms of empowerment perception. Married employees were found to be significantly above of the single group at all variables. Finally; scores for all research variables tend to increase with age, tenure, and position of the employees.

\section{DISCUSSION}

Empowering environmental factors as organizations' culture, climate, or management practices all contribute to the levels of work engagement. However, this effect is not alone. A major additive is related with how these factors are perceived by the employees. So, the psychological aspect of empowerment is agent through the stated effect.

First, the nourishing leadership style, consists the emic texture of paternalistic behavior, has found to be the most contributing to work engagement among other styles. Authoritarian followed nourishing, but laissez-faire has not found to be significantly effective on engagement. Its $\beta$ value $(-118)$ was negative indeed though not significant. Secondly, impact/self determination dimension of psychological empowerment was not significant on work engagement. Only the meaning/competence dimension was effective.

These results may be commented as employees from cultures high on uncertainty avoidance and highpower distance may expect the leader to take charge, give orders and prefer to be told what to do instead of ambiguity. The family like environment, caring and protective style of their leader also may help them to find meaning and feel competent in their work. Collectivism may keep them from being on the forefront. Clearly, these are important findings for future research and managerial practice, in order to apply empowerment as an effective management technique.

One of the eye-catching findings related to leadership was the elimination of 5 of the 6 ethical leadership style items in factorial analyses. The amount of empirical studies to test the impact of ethical leadership style on engagement and empowerment is not sufficient until present (Arslantaş \& Dursun, 2008). The main reason of it maybe the newly burgeoning familiarity of business world with positive effects of the ethical considerations on desired outcomes in the long run for both organizations and society (Tevrüz, 2007). Existing research indicates the contribution of ethical leadership to organizational citizenship behavior, organizational commitment and the reduction of 
counterproductive work behavior (Brown \& Trevino, 2006). Accordingly, it is commented that ethical leadership is an issue that needs more attention in terms of academic studies.

Findings related with demographic variables are also worthy of elaboration. With regard to tenure, age, and vocation the levels of engagement and empowerment (psychological as well) showed significant differences among groups. Employees at higher positions, with more tenure and age, tend to rate more favorable empowerment environment, feel more powerful and engaged. Koberg et al., 1999) also reported that individuals with more tenure and in higher ranks in the organization felt more empowered. Literature holds similar findings to ours (Koberg et al., 1999; Ton, 2008; Laschinger et al., 2009a; Laschinger et al., 2009b).

The results mentioned in the previous paragraph can be supported from the perspective of career development theories as well. These theories pronounce, people pass through specific career stages during their life span. Stages usually are, based on chronological age though the age ranges assigned for each stage have varied considerably between empirical studies (Kaur \& Sandhu, 2010). The common point of them is that stages are mostly categorized as early, middle, and late. This categorization partially corresponds to the exploration, establishment, and maintenance stages of Super's theory (Kaur \& Sandhu, 2010).

Ornstein et al. (1989) argued that career stages can be based either on age or on organizational, positional or professional tenure. When tenure measures are used, the first two years are seen as a trial period. The period from two to ten years means establishment period in which an individual is concerned with career advancement and growth. After ten years comes the maintenance period in which the individual prefers to hold on to the accomplishments achieved.

Accordingly, employees with more age and experience in work life are considered to be more settled down and stable in terms of their decisions. They will be more competent in their jobs. Additionally, as reported by Lin (2002) for Chinese culture and tradition, in traditional Turkish culture also age is valued and respected. Older people are accepted to have capability, respectfulness, trustworthiness, and loyalty. So that, in sum, it is expected that they may experience more engagement and empowerment.

Western literature has reported that men and women show no significant differences in their attitude toward empowerment (Koberg et al., 1999). However, this result may not apply to an Eastern culture in which women are generally less privileged and have less power in organizations (Lin, 2002). Our finding in terms of gender differences reveals that male employees perceive more empowerment than their female colleagues. The comment for it could be charged to culture impact, with no strain. However, conflicting results are also prevalent in literature. Research in Malaysia with five star hotel front-office employees conducted by Patah (2009) manifests no significant differences of empowerment with respect to sex and tenure. Zani \& Pietrantoni (2001) indicates that, based on a study in health sector, females perceive more empowerment. In India, for empowerment perception among male and female computer programmers any significant differentiation was not found (Krishna, 2005). More research particularly on gender differences in terms of empowerment will be valuable to be clear on the issue.

Another demographical characteristic, education, did not exert a significant difference for any of the variables in our research model. Lin's (2002) findings in terms of empowerment are similar and she assumes that it may reflect a performance-oriented system in companies. She indicated that in Taiwan, the reward system in insurance companies is very much performance oriented. Promotion and compensation are mainly based on performance rather than on educational qualifications' (p.15). As presented earlier, leader styles in this study are found to be performance and organizational goals oriented. So, Lin's explanation may be viable for our results as well.

One last word; in terms of hotels participated in our study, the highest level of empowerment and engagement is found to be among the world's chain hotels group. The least engagement and empowerment exists in the seaside hotels of Turkey. In terms of psychological empowerment the Turkish chain hotels are the leading group. However, hotel is a negatively contributing variable to work engagement due to regression analyses' results. This finding gives rise to thought of the unsatisfying context for employees working in hotels to feel engaged. As empowerment is an effective concept on engagement, hotel managers may need to be more trained to apply the proper way of creating empowerment. More research conducted particularly in hotels located in Turkey and other countries as well may provide highlights for improvement. 


\section{REFERENCES}

Aksoy, B. (2008), The relationship between paternalistic leadership, empowerment, and turnover intention: an empirical study. Yayınlanmamış yüksek lisans tezi. Marmara Üniversitesi Sosyal Bilimler Enstitüsü, İngilizce İşletme Anabilim Dalı, Örgütsel Davranış Bilim Dalı, İstanbul.

Anderson, N.; Öneş, D. S., Sinangil, H. \& Viswesvaran, C. (2002), Handbook of Industrial, Work \& Organizational Psychology. 2, (2nd Edition) London: Sage Publications.

Arslantaş, C. (2007), 'Güçlendirici lider davranışının psikolojik güçlendirme üzerindeki etkisini belirlemeye yönelik görgül bir çalışma’. Anadolu Üniversitesi Sosyal Bilimler Dergisi. 7, (2), 227-40.

Arslantaş, C. \& Dursun, M. (2008), 'Etik liderlik davranışının yöneticiye duyulan güven ve psikolojik güçlendirme üzerindeki etkisinde etkileşim adaletinin dolaylı yolu'. Anadolu Üniversitesi Sosyal Bilimler Dergisi. 8, (1), 111-128.

Avolio, B. J.; Zhu, W.; Koh, W. \& Bhatia, P. (2004), 'Transformational leadership and organizational commitment: mediating role of psychological empowerment and moderating role of structural distance'. Journal of Organizational Behavior.25, (8), 951-68.

Bakker, A. B. \& Demerouti, E. (2008), 'Towards a model of work engagement'. Career Development International.13, (3), 209-23.

Bakker, A. B. \& Demerouti, E. (2007), 'The job demands-resources model: state of the art'. Journal of Managerial Psychology. 22, (3), 309-28.

Barbuto, J. E. Jr. \& Wheeler, D. W. (2006), 'Scale development and construct clarification of servant leadership'. Group and Organization Management. 31, (3), 300-26.

Bass, B. M. (1985), 'Leadership: good, better, best'. Organizational Dynamics. 13, (3), 26-40.

Bass, B. M. (1990), Bass \& Stogdill's Handbook of Leadership. The Free Press Macmillan Inc., New York, USA.

Bennis, W. G. \& Nanus, B. (1986), Leaders: The Strategies for Taking Charge (2. Edition). Newyork: Harper \& Row publications.

Brown, M. E.; Trevino, L. K. \& Harrison, D. (2005), 'Ethical leadership: a social learning perspective for construct development and testing'. Organizational Behavior and Human Decision Processes. 97, (2), 117-134.

Brown, M. E. \& Trevino, L. K. (2006), 'Ethical leadership: a review and future directions'. The Leadership Quarterly.17, (4), 595-616.

Bowen, D. E. \& Lawler, E. E. (1992), 'The empowerment of service workers: What, why, how, and when'. Sloan Management Review. 33, (3), 31-39.

Casey, M.; Saunders, J. \& Ohara, T. (2009), 'Impact of critical social empowerment on psychological empowerment and job satisfaction in nursing and midwifery settings'. Journal of Nursing Management.17, (5), 1-11.

Conger, J. A. \& Kanungo, R. N. (1988), 'The empowerment process: Integrating theory and practice'. Academy of Management Review. 13, (3), 471-82.

Conger, J. A. (1999), 'Charismatic and transformational leadership in organizations: an insider's perspective on these developing streams of research'. The Leadership Quarterly.10, (2), 145-79.

Conger, J. A. \& Kanungo, R. N. (1987), 'Toward a behavioral theory of charismatic leadership in organizational settings'. Academy of Management Review. 12, (4), 637-47.

Demir, H. \& Okan, T. (2008), 'Etkileşimsel ve dönüşümsel liderlik: bir ölçek geliştirme denemesi’' Yönetim Dergisi.19, (61), 72-90.

Ergin, C. (2000), ‘Türkiye'deki örgütlerde çatışmaların çözümlenmesine ilişkin çalışmalar'. Türkiye'de Yönetim, Liderlik ve İnsan Kaynakları Uygulamaları. Edi. Zeynep Aycan. Türk Psikologlar Derneği Yayınları, No.21, 1. Basım, Ankara.

Erstad, M. (1997), „Empowerment and organizational change“. International Journal of Contemporary Hospitality Management. 9, (7), 325-33.

Fikret-Paşa, S. (2000), ‘Türkiye ortamında liderlik özellikleri’. Türkiye’de Yönetim, Liderlik ve İnsan Kaynakları Uygulamaları. Edi. Zeynep Aycan. Türk Psikologlar Derneği Yayınları, No.21, 1. Basım, Ankara. 
Harter, J. K.; Schmidt, F. L. \& Hayes, T. L. (2002), 'Business-unit-level relationship between employee satisfaction, employee engagement, and business outcomes: a meta-analysis'. Journal of Applied Psychology. 87,(2), 268-79.

Hofstede, G. (2001), Culture's Consequences. London: Sage Publications.

Honold, L. (1997), ' A review of the literature on employee empowerment'. Journal of Empowerment in Organizations. 5, (4), 202-12.

Howell, J. M. \& Avolio, B. J. (1993), ‘Transformational leadership, transactional leadership, locus of control, and support for innovation: key predictors of consolidated-business-unit-performance'. Journal of AppliedPsychology.78, (6),891-902.

Joseph, E. E. \& Winston, B. E. (2005), 'A correlation of servant leadership, leader trust, and organizational trust'. Leadership and Organizational Development Journal. 26, (1), 6-22.

Judge, A. T. \& Piccolo, R. F. (2004), 'Transformational and transactional leadership: a meta-analytic test of their relative validity'. Journal of Applied Psychology. 89, (5), 755-68.

Kaur, K. \& Sandhu, H. S. (2010), 'Career stage effect on organizational commitment: empirical evidence from Indian Banking Industry'. International Journal of Business and Management. 5, (12), 141-52.

Krishna, Y. R. (2005), 'Psychological empowerment and organizational commitment: an empirical study of software programmers in India'. www.scribd.com

Koberg, C. S., Boss, R. W., Senjem, J. C., \& Goodman, E. A. (1999). 'Antecedents and outcomes of empowerment'. Group \& Organization Management, 24(1), 71- 91

Laschinger, H. S., Wilk, P., Cho, J., Greco, P. (2008), 'Empowerment, engagement and perceived effectiveness in nursing work environments: does experience matter?' Journal of Nursing Management. 23, (2), 11-32.

Laschinger, H. S., Wilk, P., Finegan, J. (2009)a, 'Context matters: the impact of unit leadership and empowerment on nurses' organizational committment'. Journal of Nursing Administration,39,(5), 228-35.

Laschinger, H. S.; Wilk, P.; Cho, J. \& Greco, P. (2009)b, 'Empowerment, engagement and perceived effectiveness in nursing work environments: Does experience matter?'. Journal of Nursing Management. $17,636-46$.

Laschinger, H. S.; Finegan, J. E. \& Shamian, J. (2001), 'Promoting nurses’ health: effect of empowerment on job strain and work satisfaction'. Nursing Economics. 19, (2), 42-52.

Laschinger, H. S. (1996), 'A theoretical approach studying work empowerment in nursing: A review of studies testing Kanter's theory of structural power in organizations'. Nursing Administration Quarterly. $20,(2), 25-41$.

Liden, R. C.; Wayne, S. J.; Zhao, H.; Henderson, D. (2008), 'Servant leadership: development of a multidimensional measure and multi-level assessment'. TheLeadership Quarterly. 19, (2), 161-77.

Lin, C. Y. (1998), 'The essence of empowerment: A conceptual model and a case illustration'. Journal of Applied Management Studies.7, (2), 223-38.

Lin, C. Y. (2002), 'Empowerment in the Service industry: An empirical study in Taiwan'. Journal of Psychology. 136, (5), 555-78.

Lowe, K. B.; Kroeck, G. K. \& Sivasubramaniam, N. (1996), 'Effectiveness correlates of transformational and transactional leadership: a meta- analytic review of the mlq literature'. The Leadership Quarterly. 7 , (3), 385- 425.

Luthans, F. (2008), Organizational Behavior. (1 $1^{\text {th }}$ Edition), Singapore: McGraw- Hill/Irwin publications.

Maslach C.; Schaufeli, W. B. \& Leiter, M. P. (2001), 'Job Burnout'. Annual Review of Psychology. 52, (1), 397-422.

Miller, A.; Goddard, P \& Laschinger, H. S. (2001), 'Evaluating physical therapists' perception of empowerment using Kanter's theory of structural power in organizations'. Physical Therapy. 81, (12), 1880-8.

Ornstein, S., \& Cron, W. L., \& Slocum, J.W. (1989), 'Life stages versus career stage: A comparative test of the theories of Levinson and Super' Journal of Organizational Behavior, 10, 117-133.

Patah, M (2009), 'the influnce of psychological empowerment on overall job satisfaction of front office receptionist'. International Journal of Business and Management.4, (11). 
Patrick, A. \& Laschinger, H. S (2006), 'The effect of structural empowerment and perceived organizational support on middle level nurse manager's role satisfaction'. Journal of Nursing Management.14, (1), 13-22.

Pellegrini, E. K. \& Scandura, T. A. (2006), 'Leader-member exchange (LMX), paternalism, and delegation in turkish business culture: an empirical investigation'. Journal of International Business Studies. 37, 26479.

Piersol, B. (2007), 'Employee engagement and power to the edge'. Performance Improvement. 46, (4), 3033.

Podsakoff, P. M.; MacKenzie, S. B.; Moorman, R. H. \& Fetter, R. (1990), 'Transformational leader behaviors and their effects on followers' trust in leader, satisfaction, and organizational citizenship behaviors'. LeadershipQuarterly. 1, (2), 107- 142.

Podsakoff, P. M.; MacKenzie, S. B.; Moorman, R. H. \& Fetter, R. (1990), 'Transformational leader behaviors and their effects on followers' trust in leader, satisfaction, and organizational citizenship behaviors'. Leadership Quarterly. 1, (2), 107-142.

Saks, A. M. (2006), 'Antecedents and consequences of employee engagement'.Journal of Managerial Psychology.21, (7), 600-19.

Schaufeli, W. B. \& Bakker, A. B. (2004), 'Job demands, job resources, and their relationship with burnout and engagement: a multi-sample study'. Journal of Organizational Behavior.25, (3), 293-315.

Stander, M. W. \& Rothman, S. (2010). 'Psychological empowerment, job insecurity and employee engagement'. Journal of Industrial Psychology. 36, (1).

Schaufeli, W. B.; Salanova, M.; Gonzalez-Roma, V. \& Bakker, A. B. (2002), 'The measurement of engagement and burnout: a two sample confirmatory factor analytic approach'. Journal of Happiness Studies. 3, (1), 71-92.

Spreitzer, G. M. (1995), 'Psychological empowerment in the workplace: Dimensions, measurment, and validation'. Academy of Management Journal. 38, (5),1442-65.

Spreitzer, G. M. (1996), 'Social structural characteristics of psychological empowerment'. Academy of Management Journal. 39, (2), 483-504.

Stone, A. G.; Russell, R. F. \& Patterson, K. (2004), 'Transformational versus servant leadership: a difference in leader focus'. The Leadership and Organization Development Journal.25, (4), 349-61.

Schaufeli, W. B. \& Bakker, A. B. (2003), Utrecht Work Engagement Scale Preliminary Manual, Version 1. www.schaufeli.com

Xanthopoulou, D.; Bakker, A. B.; Demerouti, E. \& Schaufeli, W. B. (2009), 'Work engagement and financial returns: a diary study on the role of job and personal resources'. Journal of Occupational and Organizational Psychology. 82, (1), 183-200.

Tevrüz, S. (2007), İş Hayatında Etik. Beta Yayıncılık: İstanbul.

Thomas, K. W. \& Velthouse, B. A. (1990), 'Cognitive elements of empowerment: An interpretive model of intrinsic task motivation'. Academy of Management Review. 15, (4), 666-81.

Trevino, L. K.; Brown, M. \& Hartman, L. P. (2003), 'A qualitative investigation of perceived executive ethical leadership: perceptions from inside and outside the executive suite'. Human Relations. 55, (1), 537.

Ton, İ. A. (2008), The effect of individualism-collectivism and trust on workplace empowerment. Doktora tezi. Marmara Üniv. Sosyal Bilimler Enstitüsü, Organizational Behavior Bilim Dalı. İstanbul.

Zani, B. \& Pietrantoni, L. (2001), 'Gender differences in burnout, empowerment and Somatic symptoms among health professionals: moderators and mediators'. Equal Opportunities International,20, 1/2), 38-49. 